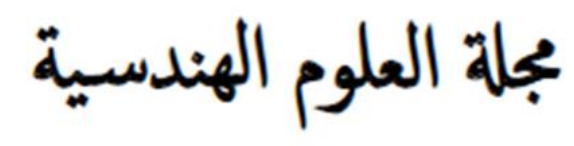

\title{
Flexible Pavement Design Suitable for Sudan
}

\author{
Esra M. O. Mohamed Elsaid 1,* , and Awad M. Mohamed ${ }^{2}$ \\ 1 University of Khartoum, Khartoum, Sudan \\ 2 Department of Road Engineering, Building and Road Research Institute, University of Khartoum, Khartoum, Sudan \\ * Corresponding author: Esra M. O. Mohamed Elsaid (e-mail: osman.esraa@ymail.com).
}

Article history: Received 12 March 2020, Received in revised form 4 November 2020, Accepted 11 November 2020

\begin{abstract}
Pavement design is the process of calculation the thickness of pavement layers which can withstand the expected traffic load over the design life without deteriorating. In another word, it is providing a pavement structure in which stresses on the subgrade are reduced to the acceptable magnitude. Highways in Sudan deteriorate in the first years of construction due to many reasons including the deficiency in pavement design. This research aims to minimize the probability of roads failure by selecting the appropriate pavement design method for Sudan based on the performance evaluation of each method. Various pavement sections with different environment, traffic loading, subgrade and material properties were designed using AASHTO, Road Note 31, Group Index and CBR design method. The layered elastic analysis and the structural number approach were adopted to evaluate the performance of these sections. The evaluation results were the base for selecting of the suitable design method. The evaluation results concludes that, the AASHTO design method is the most suitable design method to withstand pavement deformations followed by Road Note 31 method. But, from economical prospective Road Note 31 method; with some modifications; can be considered as the suitable design method for Sudan. Recommendations for future studies focus on the development and implementation of mechanistic-empirical pavement design guide applicable in Sudan.
\end{abstract}

Keywords: Flexible, Performance, Pavement Design, Stress, Traffic.

\section{INTRODUCTION}

\section{A. General Background}

The structural design of pavements is not an exact science and, therefore, it is not possible to formulate one set of design criteria that could meet the requirements of every road. Traffic conditions, climate and geology, materials of construction, and of course, economics, are the variables that demand from the engineer the fullest application of his professional judgment and engineering skills [1].

There are two major types of pavements: flexible or asphalt pavements, rigid pavements. Rigid pavements generally consist of concrete slab surface over an appropriate foundation (base and subbase layers). Though, due to the large construction cost, the main usages of rigid pavement are constructing airports, heavily duty major highways and industrial floor slabs.

This research focuses on the design of flexible pavements which are defined as those layered structures which have a flexible response under the repeated traffic load. They mainly consist of asphalt concrete surface, base and subbase layers.

Most highway projects in Sudan damage or fail in a short time due to deficiency in design, lack of materials and quality control of construction work. Deficiency in design is caused by using variable design methods that might not be suitable for traffic, environment and available construction materials in Sudan. Also, some design methods are used with missing design data, therefore most of the designed roads are not safe and efficient. 
B. Research objectives

i. To compare the pavement structure components for roads designed using different flexible pavement design methods (AASHTO, Road Note 31, Group Index and CBR)

ii. To evaluate the performance of each design method by using layered elastic analysis and the structural number approach

iii. To select the suitable pavement design method for Sudan based on the performance evaluation of each design method

\section{METHODS}

To evaluate the performance of different pavement design methods (AASHTO, Road Note 31, Group Index and CBR [2] [3] [4]). The method adopted in this study followed the below sequence:

- Obtain the required input data to design the pavement sections.

- Determine the expected traffic load in terms of equivalent single axle load (ESAL) for the entire design period.

- Determine the minimum pavement structure required to withstand the expected traffic using the four design methods.

- Compare the pavement strength of each design method using the structural number approach.

- Compute tensile strain at the bottom of the asphalt layer and the compressive strain at the top of the subgrade soil using layered elastic analysis software (Mnpave computer program) developed by Minnesota Department of Transportation (Mn/DOT) [2].

- Compute pavement responses (fatigue deformation, rutting deformation, service life and allowable repetitions to failure) based on different response models using layered elastic analysis results.

- Evaluate and compare the performance of each design method based on expected service life before failure due to fatigue and rutting deformations.

- Carry out an economic feasibility study for all design methods, to validate the cost per kilometre for each method in order to select the most economic design method.

\section{THEORY/CALCULATION}

\section{A. Literature Review}

\section{1) Pavement Design Factors}

Design factors for flexible pavement can be divided into five broad categories that are, traffic and loading, environmental conditions, pavement performance, construction materials and subgrade properties.

\section{2) Layered Elastic Analysis}

It is generally accepted that pavements are best modeled as a layered system, consisting of layers of various materials. The Layered Elastic Analysis is a mechanistic procedure capable of determining pavement responses (stress and strain) in flexible pavement and works with relatively simple mathematical models and thus, requires some basic assumptions. These assumptions are [1]:

i. Each layer is homogeneous, isotropic, and linearly elastic, characterized by Young's modulus of elasticity, E, and Poisson's ratio, $\mu$.

ii. The material is weightless and horizontally infinite

iii. The thickness of each layer is finite, and the subgrade is considered as infinite layer.

iv. The load is uniformly applied on the surface over a circular area.

v. Continuity conditions are satisfied at the layer interfaces.

vi. Materials are not stressed beyond their elastic ranges.

In multi layered pavement system [3], the locations of the various stresses in a three- layered pavement system are as shown in figure 1. In pavement analysis, loads on the surface of the pavement produce two strains which are believed to be critical for design purposes. These are the horizontal tensile strain at the bottom of the asphalt layer and the vertical compressive strain at the top of the subgrade layer, and they are given by equations 1 and 2 respectively;

$$
\begin{aligned}
& E_{\mathrm{t}}=\frac{\sigma_{\mathrm{r} 1}}{\mathrm{E}_{1}}-\mu_{1} \frac{\sigma_{\mathrm{r} 1}}{\mathrm{E}_{1}}-\mu_{1} \frac{\sigma_{\mathrm{z} 1}}{\mathrm{E}_{1}} \\
& \mathrm{E}_{\mathrm{v}}=\frac{1}{\mathrm{E}_{\mathrm{g}}}\left(\sigma_{\mathrm{z} 2}-\sigma_{\mathrm{r} 3}\right)
\end{aligned}
$$

Where;

et: horizontal tensile strain at the bottom of the asphalt concrete layer 
ez: vertical compressive strain at the top of the subgrade

oz1: vertical stress at interface 1 (bottom of asphalt concrete layer)

$\sigma \mathrm{z} 2$ : vertical stress at interface 2

or1: horizontal stress at the bottom of layer 1

бr2: horizontal stress at the bottom of layer 2

or3: horizontal stress at the top of layer 3

$\mu$ : Poisson's ratio of the layer

E1 and E3 receptively, are modulus of elasticity of layer 1 and 3.

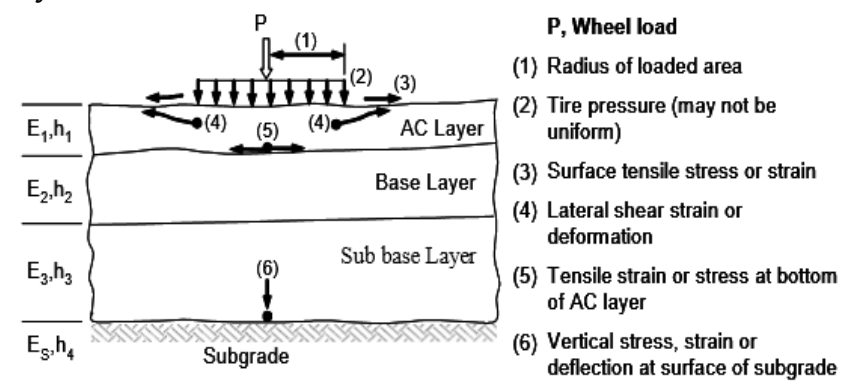

Fig. 1. Fundamental pavement responses as a function of load, material properties and layer thicknesses

\section{a) Failure Criteria}

If the horizontal tensile strain is excessive, cracking of the surface layer will occur, and the pavement distresses due to fatigue. If the vertical compressive strain is excessive, permanent deformation occurs at the surface of the pavement structure from overloading the subgrade, and the pavement distresses due to rutting.

Most of the fatigue failure models take the following form [1]:

$$
N_{f}=f_{1} e_{t}{ }^{-f 2} E_{1}{ }^{-f 3}
$$

While the rutting models usually take the following form:

$$
\mathrm{N}_{\mathrm{r}}=\mathrm{f}_{4}\left(\mathrm{e}_{\mathrm{v}}\right)^{-\mathrm{f} 5}
$$

Where:

$\mathrm{N}_{\mathrm{f}}$ is the allowable number of load repetitions to prevent fatigue cracking from reaching a certain limit (10-20\% of the pavement surface area)

$\mathrm{N}_{\mathrm{r}}$ the allowable number of load repetitions to prevent rutting from reaching a certain limit $(0.5$ in.);

$\mathrm{et}_{\mathrm{t}}$ the tensile strain on the bottom of the asphalt layer

$\epsilon_{v}$ the compressive vertical strain on the surface of sub- grade

$E_{1}$ the elastic modulus of the asphalt layer $f_{1}, f_{2}, f_{3}, f_{4}, f_{5}$ is the regression coefficients. b) Damage Prediction

The incremental damage is summed for all axle loads to obtain the expected damage factor over the life of the pavement. The damage factor is given by:

$$
\mathrm{D}=\sum \frac{\mathbf{N}_{1}}{\mathbf{N}_{\mathbf{r}}}
$$

Where;

D: Damage factor

$\mathrm{N}_{\mathrm{i}}$ : Actual number of load repetitions

$\mathrm{Nr}$ : Number of load repetitions to failure

If $\mathrm{D}$ is less than a value of one, then the pavement can be expected to exceed its design life, if $\mathrm{D}$ is greater than one, the pavement is expected to fail prematurely. If this value is much less than one, the pavement is probably designed too conservatively.

3) Methods of Flexible Pavement Design

The various design philosophies used by a number of road authorities over the years, can be divided into five broad categories [4]:

- Empirical design methods with or without a soil strength test

- Mechanistic-empirical design methods

- Regression methods based on pavement performance or road tests

- Theoretical design methods

- Limiting deflection methods

The design methods which nominated for this study are:

a) AASHTO

It is a regression method based on the results of the AASHTO Road Test conducted from 1958-1960 in Ottawa, Illinois [5]. The detailed design procedure is illustrated in AASHTO Guide for Design of Pavements Structures as in [6].

b) Road Note 31

It is an empirical method which gives recommendations for the structural design of bituminous surfaced roads in tropical and subtropical climates. Also, it is appropriate for roads which are required to carry up to 30 million cumulative equivalent standard axles in one direction. The steps of design are illustrated in the note as in [7].

c) Group Index

It is an empirical method which is based on the physical properties of the sub-grade soil. 


\begin{tabular}{|c|c|c|c|c|}
\hline \multicolumn{5}{|c|}{ TABLE 1: GENERAL DESIGN INPUT DATA } \\
\hline \multirow[b]{2}{*}{ 2) } & \multirow[b]{2}{*}{ 3) Pavement Section } & \multirow{2}{*}{$\begin{array}{l}\text { 4) ES } \\
\text { AL } \\
(\times 106 \\
)\end{array}$} & \multicolumn{2}{|c|}{$\begin{array}{l}\text { 5) Subgrade } \\
\text { Properties }\end{array}$} \\
\hline & & & $\begin{array}{l}\text { 6) C } \\
\text { BR } \\
(\%) \\
\end{array}$ & $\begin{array}{c}\text { 7) Class. } \\
\text { (AASHT } \\
\text { O) }\end{array}$ \\
\hline 8) & 9) Al Obaid Internal Roads & 10) 0.7 & 11)5 & 12) (A-2-4) \\
\hline 13 & 14) Rosairies - Umbarid & 15) 1 & 16) 2 & 17)(A-7-5) \\
\hline 18) & 19) Nawa - El Sleem & $\begin{array}{c}20) 1.5 \\
3\end{array}$ & 21)3 & 22) (A-7-6) \\
\hline 23) & 24) Dongola Kajbar Road & 25)3 & $\begin{array}{c}26) 1 . \\
2 \\
\end{array}$ & 27) $(A-7-6)$ \\
\hline 28) & 29) Proposed Road 1 (S.Kordufan) & 30) 5 & $\begin{array}{c}\text { 31) } 7 . \\
5\end{array}$ & 32) (A-2-6) \\
\hline 33. & 34)Mohamed Nageeb Street & $35) 7.3$ & $36) 8$ & 37) (A-2-6) \\
\hline 38 & 39)Obiad Khatim Street & $40) 8$ & $41) 3$ & 42)(A-3) \\
\hline 43. & 44) Proposed Road 2 (Red Sea St.) & $45 \lcm{9}$ & 46) 12 & 47)(A-1-a) \\
\hline 48) & 49) Proposed Road 3 (Northern St.) & $50) 12$ & 51) 4 & 52)(A-3) \\
\hline 53 & 54)Proposed Road 4 (Al Jazira St.) & 55) 13 & 56) 2 & 57)(A-7-6) \\
\hline 58 & 59) Proposed Road 5 (W.Darfur St.) & $60) 15$ & 61) 10 & 62)(A-2-4) \\
\hline 63 & 64) Al Steen Street & $\begin{array}{c}65) 18 . \\
6 \\
\end{array}$ & 66) 3 & 67) (A-4) \\
\hline 68 & 69) Al Eilfoon Road & $\begin{array}{c}70) 19 . \\
6\end{array}$ & 71) 4 & 72) (A-7-5) \\
\hline
\end{tabular}

d) $C B R$

California bearing ratio design method (CBR) is an empirical method which prompted by the U.S. Corps of Engineers which adopted the CBR test in developing their flexible pavement design for airport runways. They later extended these design criteria to include highway traffic loading [8].

4) Review of Previous Researches

Regis L. Carvalho in 2006 presented a comparison of flexible pavement designs between the 1993 AASHTO guide and the NCHRP 1-37A methodology and a sensitivity analysis of the NCHRP 1-37A's input parameters [9]. The outcomes were states with higher average temperatures had worse performance than those with mild to low average temperatures, indicating that the 1993 AASHTO Guide possibly overestimates the performance (or underestimates the required pavement thickness) for the warm locations.

Emmanuel O. Ekwulo and Dennis B. Eme carry out a layered elastic analysis of pavements designed using three known CBR methods; the Asphalt Institute, the National Crushed Stone Association and the Nigerian CBR methods. It was concluded that flexible pavements designed using the three known CBR methods are prone to failure due rutting deformation and recommended the use of mechanistic procedures in the design of flexible pavements in developing tropical countries [10].

\section{B. Calculation}

\section{1) Layers Thickness Calculation}

Different roads were designed using AASHTO, Road Note 31, Group Index and CBR design methods with the design inputs presented in table 1 and the criteria illustrated in the guide of each method. The design life was taken as 20 years for all sections.

The structural number - which is the parameter that represents the pavement structural strength was calculated based on layers thickness (D), layers coefficient (a) and drainage coefficients (m) by using equation (6) [2]. The values of drainage coefficients were taken typically equal to 1 , and the layers coefficients were $\mathrm{a}_{1}=0.42, \mathrm{a}_{2}=0.134$ and $\mathrm{a}_{3}=0.11$. The structural design for all the pavement sections is summarized in table 2 .

$$
\mathrm{SN}=\mathrm{a}_{1} \mathrm{D}_{1}+\mathrm{a}_{2} \mathrm{D}_{2} \mathrm{~m}_{2}+\mathrm{a}_{3} \mathrm{D}_{3} \mathrm{~m}_{3}
$$

\section{3) Layered elastic analysis of pavement sections}

The Mnpave computer program [5] was used to calculate the strains which are incorporated in the fatigue cracking and rutting models to estimate the number of load applications to failure, damage factor and service life for different pavement sections. The concept of this program is to apply a static load on a circular plate placed on a single axle single wheel configuration. A tire load of $40 \mathrm{kN}$ and pressure of $552 \mathrm{kpa}$ was adopted in this analysis.

In the performance evaluation, the greater value of fatigue and rutting damages is considered as the failure criteria for the pavement sections.

\section{RESULTS AND DISCUSSION}

\section{A. Results}

The results of structural thickness design carried out for AASHTO, Road Note 31, Group Index and CBR design methods were presented in table 2, while the result of the layered elastic analysis and the pavement response were presented in table 3 .

\section{1) Cost Calculation for each design method}

The aim of cost calculation is to evaluate the economic feasibility of each design method. For this purpose, the quantity of materials for each pavement layer for one kilometre road length, $7 \mathrm{~m}$ carriageway and $1.5 \mathrm{~m}$ shoulder width were calculated and priced according to the Sudan 
Ministry of Infrastructures updated prices [11].

The bill of quantities for Proposed Road 3 is presented in table 4 .

TABLE 2: ROAD SECTIONS DESIGN OUTPUT

\begin{tabular}{|c|c|c|c|c|c|c|}
\hline \multirow{2}{*}{ \# } & \multirow{2}{*}{$\begin{array}{l}\text { Pavement } \\
\text { Section }\end{array}$} & \multirow{2}{*}{$\begin{array}{c}\text { Pavement } \\
\text { layerA }\end{array}$} & \multicolumn{4}{|c|}{ Thickness (mm) } \\
\hline & & & AASHTO & TRL & GI & CBR \\
\hline \multirow{5}{*}{1} & \multirow{5}{*}{$\begin{array}{c}\text { Al Obaid } \\
\text { Internal Roads }\end{array}$} & 1 & 100 & 50 & 50 & 50 \\
\hline & & 2 & 150 & 175 & 200 & 150 \\
\hline & & 3 & 200 & 225 & - & 390 \\
\hline & & 4 & - & - & - & - \\
\hline & & $\mathrm{SN}$ & 3.31 & 2.72 & 1.88 & 3.31 \\
\hline \multirow{5}{*}{2} & \multirow{5}{*}{$\begin{array}{l}\text { Al Haj yousif } \\
\text { Road One }\end{array}$} & 1 & 100 & 50 & 50 & 50 \\
\hline & & 2 & 150 & 175 & 200 & 150 \\
\hline & & 3 & 200 & 175 & 200 & 475 \\
\hline & & 4 & - & 200 & - & - \\
\hline & & SN & 3.31 & 3.22 & 2.75 & 3.68 \\
\hline \multirow{5}{*}{3} & \multirow{5}{*}{$\begin{array}{c}\text { Nawa - El } \\
\text { Sleem Road }\end{array}$} & 1 & 110 & 50 & 50 & 50 \\
\hline & & 2 & 150 & 175 & 190 & 150 \\
\hline & & 3 & 210 & 200 & 210 & 570 \\
\hline & & 4 & - & 225 & - & - \\
\hline & & $\mathrm{SN}$ & 3.52 & 3.41 & 2.74 & 4.09 \\
\hline \multirow{5}{*}{4} & \multirow{5}{*}{$\begin{array}{c}\text { Dongola } \\
\text { Kajbar Road }\end{array}$} & 1 & 130 & 50 & 50 & 50 \\
\hline & & 2 & 150 & 175 & 200 & 150 \\
\hline & & 3 & 560 & 200 & 240 & 750 \\
\hline & & 4 & - & 400 & - & - \\
\hline & & SN & 5.37 & 4.03 & 2.92 & 4.87 \\
\hline \multirow{5}{*}{5} & \multirow{5}{*}{$\begin{array}{l}\text { Proposed } \\
\text { Road } 1\end{array}$} & 1 & 140 & 50 & 50 & 50 \\
\hline & & 2 & 150 & 175 & 175 & 150 \\
\hline & & 3 & - & 250 & 175 & 315 \\
\hline & & 4 & - & - & - & - \\
\hline & & SN & 3.11 & 2.83 & 1.97 & 2.98 \\
\hline \multirow{5}{*}{6} & \multirow{5}{*}{$\begin{array}{c}\text { Mohamed } \\
\text { Nageeb Street }\end{array}$} & 1 & 140 & 50 & 50 & 50 \\
\hline & & 2 & 150 & 200 & 175 & 150 \\
\hline & & 3 & 200 & 200 & 175 & 290 \\
\hline & & 4 & - & 75 & - & - \\
\hline & & $\mathrm{SN}$ & 3.97 & 3.01 & 1.97 & 2.87 \\
\hline & & 1 & 140 & 50 & 50 & 50 \\
\hline & & 2 & 150 & 200 & 250 & 150 \\
\hline 7 & $\begin{array}{l}\text { Obiad Khatım } \\
\text { Street }\end{array}$ & 3 & 330 & 200 & - & 595 \\
\hline & & 4 & - & 300 & - & - \\
\hline & & $\mathrm{SN}$ & 4.54 & 3.81 & 2.15 & 4.19 \\
\hline & & 1 & 150 & 50 & 50 & 50 \\
\hline & & 2 & 150 & 200 & 200 & 150 \\
\hline 8 & Proposed & 3 & - & 200 & - & 150 \\
\hline & & 4 & - & - & - & - \\
\hline & & $\mathrm{SN}$ & 3.27 & 3.01 & 1.88 & 2.27 \\
\hline & & 1 & 150 & 125 & 100 & 50 \\
\hline & & 2 & 150 & 225 & 150 & 150 \\
\hline 9 & Proposed & 3 & 250 & 225 & 150 & 215 \\
\hline & & 4 & - & 200 & - & - \\
\hline & & SN & 4.35 & 4.94 & 2.66 & 2.55 \\
\hline & & 1 & 150 & 50 & 100 & 50 \\
\hline & & 2 & 210 & 200 & 200 & 150 \\
\hline 10 & $\begin{array}{l}\text { Proposed } \\
\text { Road } 4\end{array}$ & 3 & 485 & 225 & 200 & 650 \\
\hline & & 4 & - & 400 & - & - \\
\hline & & $\mathrm{SN}$ & 5.69 & 4.27 & 3.14 & 4.43 \\
\hline & & 1 & 150 & 50 & 50 & 50 \\
\hline & & 2 & 200 & 200 & 250 & 150 \\
\hline 11 & $\begin{array}{l}\text { Proposed } \\
\text { Road } 5\end{array}$ & 3 & - & 200 & - & - \\
\hline & & 4 & - & 100 & - & - \\
\hline & & SN & 3.54 & 3.1 & 2.15 & 1.62 \\
\hline & & 1 & 150 & 150 & 100 & 50 \\
\hline 12 & $\mathrm{Al}$ Steen Street & 2 & 210 & 250 & 200 & 150 \\
\hline & & 3 & 370 & 250 & 200 & - \\
\hline
\end{tabular}

\begin{tabular}{c|c|c|c|c|c|c}
\hline \hline & 4 & - & 200 & - & - \\
\cline { 3 - 7 } & & SN & 5.19 & 5.59 & 2.88 & 1.62 \\
\hline \multirow{4}{*}{\begin{tabular}{c}
13 \\
\cline { 3 - 7 }
\end{tabular}} & $\begin{array}{c}\text { Al Eilfoon } \\
\text { Road }\end{array}$ & 1 & 150 & 50 & 50 & 50 \\
\cline { 3 - 7 } & 2 & 210 & 200 & 250 & 150 \\
\cline { 3 - 7 } & 3 & 840 & 225 & 280 & - \\
\cline { 3 - 7 } & 4 & - & 400 & - & - \\
\cline { 3 - 7 } & & SN & 7.23 & 4.27 & 3.36 & 1.62 \\
\hline
\end{tabular}

A: 1: Asphalt concrete surface, 2: Base course, 3: Subbase course, 4: Selected fill material

TABLE 3: RESULTS OF THE LAYERED ELASTIC ANALYSIS

\begin{tabular}{c|c|c|c|c|c|c|c|c}
\hline \hline \multirow{2}{*}{$\begin{array}{c}\text { Road Sect. } \\
\text { No. }{ }^{1}\end{array}$} & \multicolumn{4}{|c|}{ Fatigue } & \multicolumn{4}{c}{ Rutting } \\
\cline { 2 - 9 } & $\mathrm{A}^{2}$ & $\mathrm{~B}^{2}$ & $\mathrm{C}^{2}$ & $\mathrm{D}^{2}$ & $\mathrm{~A}^{2}$ & $\mathrm{~B}^{2}$ & $\mathrm{C}^{2}$ & $\mathrm{D}^{2}$ \\
\hline
\end{tabular}

\begin{tabular}{|c|c|c|c|c|c|c|c|c|}
\hline \multicolumn{9}{|c|}{ 1. Damage Factor } \\
\hline 1 & 0.9 & 2.5 & 2.8 & 2.7 & 1 & 2.1 & 18.7 & 0.5 \\
\hline 2 & 1.2 & 3.2 & 3.3 & 3.5 & 0.9 & 1.7 & 7.6 & 0.4 \\
\hline 3 & 1.3 & 3.5 & 3.3 & 3.8 & 2.2 & 2.4 & 5.8 & 0.6 \\
\hline 4 & 1.4 & 3.9 & 3.7 & 4.2 & 2.1 & 2.6 & 6.3 & 0.6 \\
\hline 5 & 1.6 & 5.2 & 5.1 & 5.5 & 4.5 & 2.7 & 13.5 & 0.7 \\
\hline 6 & 1.5 & 5.6 & 4.5 & 6.2 & 2.6 & 1.6 & 2.4 & 3.3 \\
\hline 7 & 2 & 6.8 & 8.6 & 7.2 & 4 & 3.5 & 35.5 & 0.9 \\
\hline 8 & 1.4 & 6.8 & 6.7 & 8 & 0.7 & 4.4 & 2.9 & 0.8 \\
\hline 9 & 1.5 & 9.3 & 8.8 & 10 & 1.4 & 5.2 & 18.7 & 1.2 \\
\hline 10 & 1.6 & 10 & 11 & 11 & 1.3 & 4.6 & 12 & 1.5 \\
\hline 11 & 3.2 & 18 & 19 & 19 & 4.4 & 5.2 & 36 & 3 \\
\hline 12 & 2.8 & 25 & 28 & 28 & 1.3 & 10 & 16 & 4.8 \\
\hline 13 & 3.4 & 25 & 27 & 28 & 4.1 & 10 & 57 & 2.9 \\
\hline 14 & 2.8 & 31 & 33 & 36 & 4.7 & 13 & 24 & 22 \\
\hline 15 & 4.1 & 6.1 & 20 & 46 & 5 & 2 & 32 & 27 \\
\hline 16 & 3.6 & 39 & 19 & 45 & 2.4 & 12 & 176 & 5.8 \\
\hline 17 & 3.9 & 52 & 49 & 61 & 3.7 & 23 & 32 & 177 \\
\hline 18 & 5.2 & 4.9 & 28 & 122 & 3.6 & 1.4 & 209 & 360 \\
\hline 19 & 4.9 & 64 & 59 & 117 & 0.3 & 19 & 51 & 359 \\
\hline
\end{tabular}

$$
\text { 2. Service Life (years) }
$$

\begin{tabular}{c|c|c|c|c|c|c|c|c}
\hline 1 & 22 & 8 & 7 & 8 & 20 & 10 & 1 & 38 \\
\hline 2 & 17 & 6 & 6 & 6 & 22 & 12 & 3 & 45 \\
\hline 3 & 15 & 6 & 6 & 5 & 9 & 8 & 3 & 33 \\
\hline 4 & 14 & 5 & 5 & 5 & 10 & 8 & 3 & 35 \\
\hline 5 & 12 & 4 & 4 & 4 & 4 & 7 & 1 & 29 \\
\hline 6 & 14 & 4 & 4 & 3 & 8 & 12 & 16 & 6 \\
\hline 7 & 10 & 3 & 2 & 3 & 5 & 6 & 1 & 23 \\
\hline 8 & 15 & 3 & 3 & 3 & 27 & 5 & 7 & 25 \\
\hline 9 & 13 & 2 & 2 & 2 & 14 & 4 & 1 & 16 \\
\hline 10 & 12 & 2 & 2 & 2 & 16 & 4 & 2 & 13 \\
\hline 11 & 9 & 1 & 1 & 1 & 5 & 4 & 1 & 7 \\
\hline 12 & 7 & 1 & 1 & 1 & 16 & 2 & 1 & 4 \\
\hline 13 & 6 & 1 & 1 & 1 & 5 & 2 & 0 & 7 \\
\hline 14 & 7 & 1 & 1 & 1 & 4 & 1 & 1 & 1 \\
\hline 15 & 5 & 3 & 1 & 0 & 4 & 10 & 1 & 1 \\
\hline 16 & 6 & 1 & 1 & 0 & 8 & 2 & 0 & 3 \\
\hline 17 & 5 & 0 & 0 & 0 & 5 & 1 & 1 & 0 \\
\hline 18 & 4 & 4 & 1 & 0 & 6 & 15 & 0 & 0 \\
\hline 19 & 4 & 0 & 0 & 0 & 79 & 1 & 0 & 0 \\
\hline
\end{tabular}

1.The road sections name's are the same as in table 1 with the same sequent.

2. A: AASHTO, B: TRL, C: GI, D: CBR 
TABLE 4: PRICED BILL OF QUANTITIES FOR DIFFERENT DESIGN METHODS

\begin{tabular}{|c|c|c|c|c|c|}
\hline Pavement layer & $\begin{array}{l}\text { Th. } \\
(\mathrm{mm})\end{array}$ & Unit & Qty. & $\begin{array}{c}\text { Unit } \\
\text { price } \\
\text { (SDG) }\end{array}$ & $\begin{array}{l}\text { Total price } \\
\text { (SDG) }\end{array}$ \\
\hline \multicolumn{6}{|c|}{ AASHTO Design Method } \\
\hline $\begin{array}{l}\text { Asphalt } \\
\text { concrete }\end{array}$ & 150 & ton & 23100 & 2,550 & $58,905,000$ \\
\hline Base & 150 & $\mathrm{~m}^{3}$ & 1740 & 355 & 617,700 \\
\hline Subbase & 250 & $\mathrm{~m}^{3}$ & 3400 & 245 & 833,000 \\
\hline \multicolumn{5}{|c|}{ Total cost } & $60,355,700$ \\
\hline \multicolumn{6}{|c|}{ Road Note Design Method } \\
\hline $\begin{array}{l}\text { Asphalt } \\
\text { concrete }\end{array}$ & 150 & ton & 19250 & 2,550 & $49,087,500$ \\
\hline Base & 250 & $\mathrm{~m}^{3}$ & 2610 & 355 & 926,550 \\
\hline Subbase & 250 & $\mathrm{~m}^{3}$ & 3060 & 245 & 749,700 \\
\hline Selected fill & 200 & $\mathrm{~m}^{3}$ & 3200 & 200 & 640,000 \\
\hline \multicolumn{5}{|c|}{ Total cost } & $\underline{\underline{51,403,750}}$ \\
\hline \multicolumn{6}{|c|}{ Group Index Design Method } \\
\hline $\begin{array}{l}\text { Asphalt } \\
\text { concrete }\end{array}$ & 100 & ton & 15400 & 2,550 & $39,270,000$ \\
\hline Base & 200 & $\mathrm{~m}^{3}$ & 1740 & 355 & $617,700.0$ \\
\hline Subbase & 200 & $\mathrm{~m}^{3}$ & 2040 & 245 & $499,800.0$ \\
\hline \multicolumn{5}{|c|}{$\begin{array}{r}\text { Total cost } \\
\end{array}$} & $\underline{\underline{40,387,500}}$ \\
\hline \multicolumn{6}{|c|}{ CBR Design Method } \\
\hline $\begin{array}{l}\text { Asphalt } \\
\text { concrete }\end{array}$ & 50 & ton & 7700 & 2,550 & $19,635,000$ \\
\hline Base & 150 & $\mathrm{~m}^{3}$ & 1740 & 355 & $617,700.0$ \\
\hline Subbase & - & $\mathrm{m}^{3}$ & 2924 & 245 & $716,380.0$ \\
\hline \multicolumn{5}{|c|}{ Total cost } & $\underline{\underline{20}, 969,080}$ \\
\hline
\end{tabular}

\section{B. Discussion}

The following sections discuss the results obtained from this study.

1) Comparison study on pavement structure and performance for different design methods

The comparison study aims to compare the layers thicknesses, structural number and performance of the pavement sections.

a) Layers thicknesses and structural number

From table 2 it may be noted that, the asphalt concrete thickness is almost the same $(50 \mathrm{~mm})$ for Road Note 31, Group Index and CBR design methods regardless the traffic load and subgrade strength, in the other hand, AASHTO design method shows variability in asphalt concrete thickness compatible with traffic level and subgrade strength which nominates it as the most reasonable method in calculations of asphalt concrete thickness.

The other layers thickness are varying depend on the traffic load and subgrade strength for all methods which is convenient for roads design.

Regarding the structural number of pavement sections, the AASHTO design method is the most appropriate design method for all traffic levels followed by Road Note 31, because they provide the greatest structural number compared with other design methods as presented in figure 2 .

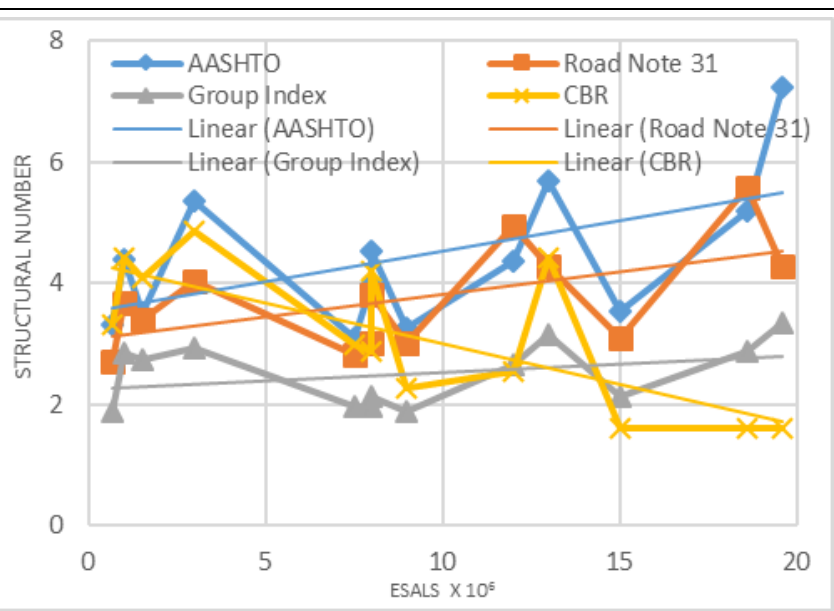

Fig. 2 Structural number verses ESAL

b) Pavement performance

Pavement performance is identified by comparing the fatigue and rutting damages for different pavement sections. Figure 3 shows that pavement sections which have the minimum fatigue damage are the sections designed by AASHTO design method, while the other methods sections will fail before the end of design life. The results also show that, fatigue damage increases with traffic load and exceeds acceptable limits for Road Note 31, Group Index and CBR methods while remains almost constant for AASHTO sections. These results indicates that, the most applicable design method to resist fatigue cracking is AASHTO method.

Trend lines in figure 4 illustrate that the most durable sections against rutting damage are the AASHTO and Road Note 31 sections followed by CBR and Group Index design methods respectively. It may be also noted that, rutting damage for Group Index and CBR methods have very high values which indicates that, these methods are not applicable for using in Sudan and their sections are expected to fail prematurely due to rutting deformation.

From the previous results, AASHTO and Road Note 31 methods are the most appropriate methods, but Road Note 31 sections have high fatigue damage values and may fail due to fatigue cracking, therefore, it can be concluded that AASHTO method is the most suitable design method to withstand both deformations.

However, Road Note 31 design method may be considered as the suitable design method for Sudan with some modifications in the calculation of asphalt concrete layer thickness in order to minimize the fatigue damage value, because its design criteria is more simple than AASHTO 
design method and all the design input parameters are available.

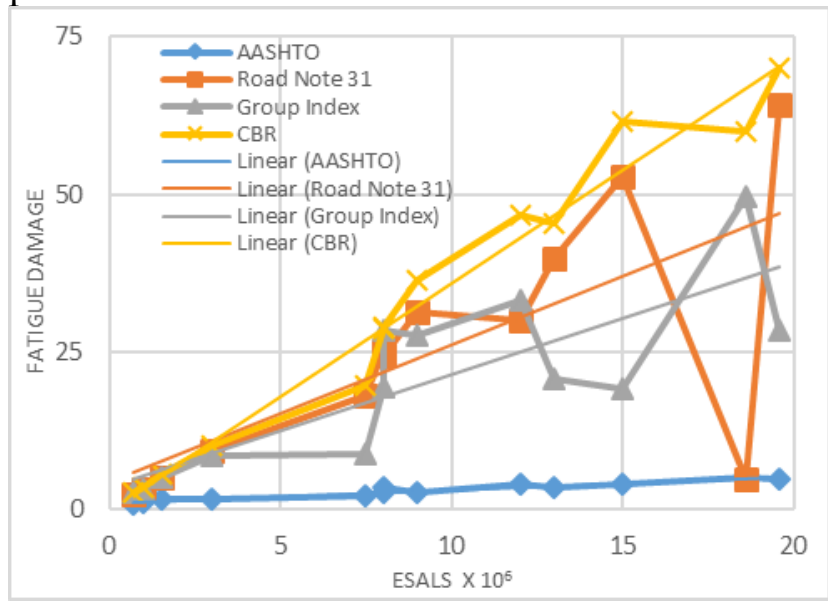

Fig. 3 Fatigue damage verses ESAL

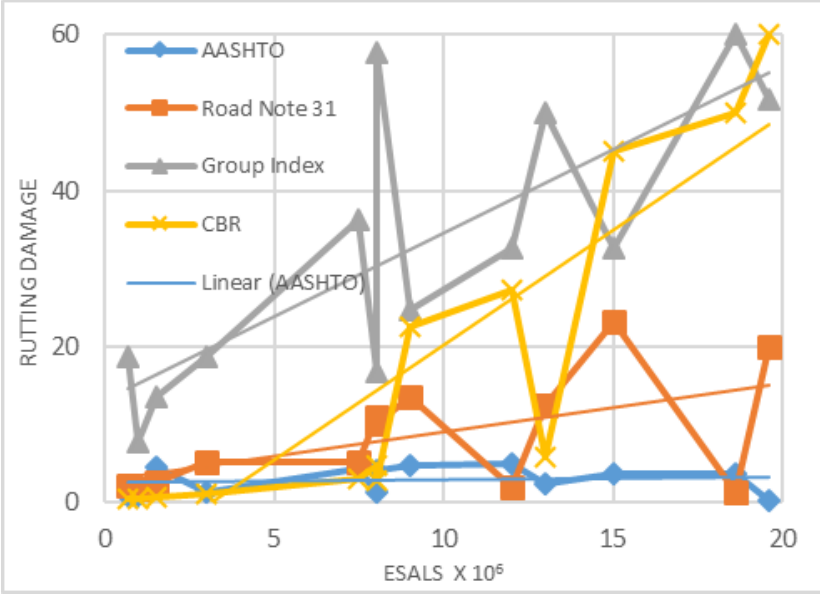

Fig. 4 Rutting damage verses ESAL

\section{2) Economic feasibility study of various design methods}

The result of cost calculations presented in figure 5 shows that, for the same pavement section and construction materials, the cost of construction for pavement designed using AASHTO method is the most expensive cost, followed by Road Note 31, Group Index and finally CBR design methods.

This result leads to the fact that, for economic and good performance roads, Road Note 31 is the most appropriate design method.

\section{CONCLUSIONS}

Regarding the analysis and findings of the present study the following results were concluded from this study:

- Rutting damage decreases as the subgrade strength increases, while the subgrade strength has insignificant effect on fatigue damage.

- The performance prediction for both rutting and fatigue damages deteriorates as the traffic level increase.

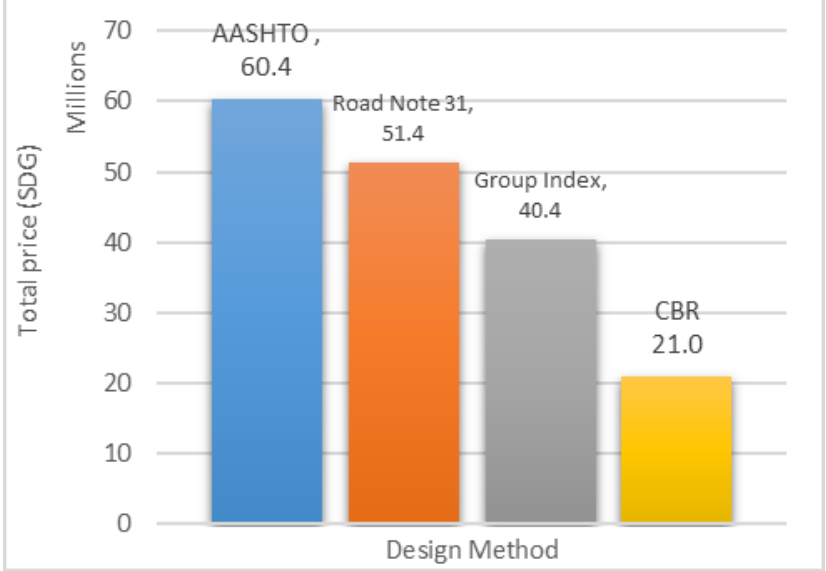

Fig. 5 Cost per 1 kilometer for different design methods

- For superior pavement performance, it is preferable to use thick asphalt layer resting on high quality base. That is because asphalt concrete layer is the most effective component for increasing pavement life against fatigue cracking.

- Regarding the structural number of the pavement sections, the AASHTO design method is the most appropriate design method for medium and heavy traffic, while CBR design method provides the highest structural number in case of light traffic.

- Flexible pavements designed using all the design methods are expected to fail before the end of their design life, because those methods were developed for regions with traffic, environment and subgrade characteristics different from Sudan, especially the AASHTO method which has poor performance in hot and warm regions (like Sudan) as verified by this study and the study carried out by Regis L. Carvalho [9].

- However, AASHTO method has the most appropriate performance against both fatigue and rutting deformations followed by Road Note 31 method. But, from economical prospective AASHTO design method is the most costive design method. Therefore, Road Note 31 method; with some modifications on the asphalt concrete thicknesses; can be considered as the suitable design method for Sudan, because its design criteria is simpler than AASHTO design method, also it is already the most commonly used design method in Sudan.

- The method adopted in this research based mainly on the performance evaluation in terms of fatigue and rutting deformations only, it is recommended to incorporate more failure 
mechanisms in the evaluation process in order to insure the pavement durability against all the excepted damages.

- This study recommended to develop mechanistic empirical pavement design method suitable for Sudan conditions to withstand the expected deformations along the design life of the pavement.

\section{REFERENCES}

[1] Y. Huang, Pavement Analysis and Design. Second Edition, New Jersey: Pearson Education, Inc., 2004.

[2] D. o. T. Minnesota, Pavement Designer's Guide Mn/DOT Flexible Pavement Design MnPAVE Beta Version 5.1, Minnesota: Office of Materials and Road Research ,Minnesota Road Research Section, Pavement Section, 2002.

[3] a. M. W. W. E. J. Yoder, Principles of Pavement Design. 2nd Ed., Wiley, New York: Wiley, 1975.

[4] B. G. L. A. P. G. Rufford, "Methods of Flexible Pavement Design - A Review," Geomechanics Journal, pp. 32-38, 1972.

[5] Highway Research Board, "The AASHO Road Test," National Research Council, Washington, DC, 1962.

[6] AASHTO, AASHTO Guide for Design of Pavements Structures, Washington, DC: American Association of State Highway and Transportation Officials, 1993.

[7] TRL, A guide to the structural design of bitumen- surfaced roads in tropical and sub-tropical countries, Crow Thorne, Berkshire, UK: Overseas Road Note No 31 TRL, 1993.

[8] D. o. A. U.S. Corps of Engineers, "The California Bearing Ratio Test as Applied to the Design of Flexible Pavements for Airports," Waterways Expt. Station, United States, 1945.

[9] R. L. Carvalho, "Mechanistic-Empirical Design of Flexible Pavements: A Sensitivity Study," Faculty of the Graduate School of the University of Maryland, College Park, 2006.

[10] O. E. a. D. B. E. Emmanuel, "Fatigue and rutting strain analysis of flexible pavements designed using CBR methods," African Journal of Environmental Science and Technology Vol. 3 (12), pp. pp. 412-421, 2009.

[11] Roads, Bridges and Drainage Corporation, Road Works Prices, Khartoum: Ministry of Infrastructures and Transport, 2018.

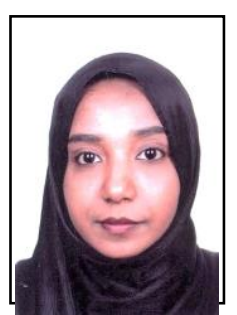

Esra Mohamed Osman Mohamed Elsaid was born in Saudi Arabia on 20 March 1993. Her educational background is as follows:

- Bachelor of Science (B.Sc. Honours) in civil engineering with first class grade, University of Khartoum, Khartoum, Sudan, 2014

- Master of Science (M.Sc.) in road technology, Building and Road Research Institute, University of Khartoum, Khartoum, Sudan, 2019

She worked as a part-time Teaching Assistant at University of Khartoum in the academic year 2014-2015, then she joined Dar Consult for Infrastructures as a Civil Engineer in the duration from April 2015 to September 2019.

Eng. Esra awarded the prize of best graduation project of the year in 2014. Also, she won the prize of association for the promotion of scientific innovation for the best Civil Engineering project in the year 2015. 